Original Contribution

\title{
WILLINGNESS-TO-PAY FOR COMMUNITY BASED HEALTH INSURANCE BY FARMING HOUSEHOLDS: A CASE STUDY OF HYGEIA COMMUNITY HEALTH PLAN IN KWARA STATE, NIGERIA
}

\author{
R. O. Babatunde ${ }^{1}$, O. A. Oyedeji ${ }^{1}$, A. E. Omoniwa ${ }^{1}$, A. H. Adenuga ${ }^{1,2 *}$ \\ ${ }^{1}$ Department of Agricultural Economics and Farm Management, University of Ilorin, Ilorin, Nigeria \\ ${ }^{2}$ Agri-Food and Biosciences Institute, Queen's University Belfast, United Kingdom
}

\begin{abstract}
The mechanism of healthcare financing available to the poor especially the farming households has been a source of worry in Nigeria. In a bid to find solution to this problem, an alternative financing scheme that will cater for healthcare expenditure of vulnerable rural farming households has been proposed. This study therefore examined the willingness-to-pay for Community Based Health Insurance (Hygiea) Scheme by farming households in Kwara state, Nigeria. 175 farming households were proportionately selected and interviewed from Edu local government area of the state. The study employed the Contingent valuation and Ordinary least square methods to analyse the average amount households are willing to pay and the factors influencing their willingness to pay respectively. The result of the study revealed that the rural farming households were willing to pay an average of N2, 139.43 per person per year (1.1 USD per person per month). The age of the household head, farm size and household monthly income were found to significantly influence the maximum amount the farming households are willing to pay. The study therefore recommended that the government should create an enabling environment that would encourage the establishment and operation of private health insurance schemes in rural areas.
\end{abstract}

Keywords: Healthcare, Income, Rural, Finance, Shonga, Kwara State, Contingent Valuation and Expenditure

\section{INTRODUCTION}

Every year, approximately 150 million people globally experience financial catastrophe, this means that they spend more than 40 percent of the income available to them on healthcare after meeting their basic needs (1). Rural households often forgo high-value care, yet still often pay substantial sums for care of low quality (2). These high health care expenditures mean a short-term health shock and can lead to debt, asset sales, and removal of children from school thereby creating longterm increases in poverty $(3,4)$. The catastrophic nature of this healthcare mechanism financing for the poor and often rural population has been a source of worry for the country and other low and middle income countries of Africa. Advocates therefore have been in favour of developing alternative financing scheme to cater for the unexpected nature of health care expenditure which should

\footnotetext{
*Correspondence to: A. H. Adenuga, Department of Agricultural Economics and Farm Management, University of Ilorin, Ilorin, Nigeria, adenugahenry@gmail.com, Phone No: $+447442765673$
}

cover vulnerable rural dwellers. The Community Based Health Insurance (CBHI) was advocated as a transitional mechanism to achieving universal coverage for health in low income countries especially the rural dwellers due to their inability to access quality health care services provided by their respective government (5).

Community Based Health Insurance (CBHI) is a not-for-profit type of health insurance that has been used by poor people to protect themselves against the high costs of seeking medical care and treatment. In CBHI schemes, members regularly pay small premiums into a collective fund which is then used to pay for health services that they require. Many CBHI schemes are designed for people that live and work in rural areas or the informal sectors which are unable to get adequate public, private, or employer-sponsored health insurance. Beneficiaries of the scheme are associated with or involved in its management, at least in the choice of the health services it covers. It is voluntary in nature, formed on the basis of mutual relationship and covers a variety of benefit packages. Any other service 
not covered by the scheme is usually borne by the household but the main idea is to cover the basic health care needs of the poor such as malaria and typhoid, tuberculosis and diarrhea. CBHIs can be initiated by health service providers, Non-Governmental-Organizations, Trade Unions, local communities, local governments or cooperatives, and can be owned and run by any of these organizations.

Several factors have recently stimulated the development of private insurance mechanisms as a means to finance health care in low-and middle-income countries. These factors include difficulties with traditional ways of health care financing, diversified consumer demand in the course of economic development and intensified trade in the health-services sector, which has introduced foreign insurance providers to developing countries. Despite numerous efforts to establish functioning healthcare systems, most people in developing countries still rely on direct payments to finance their healthcare needs. In some regions, these out-of-pocket payments can account for up to 80 per cent of total health expenditure. Private prepaid programs, such as Community-based health insurance schemes, are often the only possible way for poor people to participate in riskpooling programs. Evidence so far suggests that private schemes such as the Hygeia Community Health Plan can improve access to health care and offer financial protection even to marginalized groups (this includes small scale farming households) (6). Despite the growing importance of Private Health Insurance (PHI), however, surprisingly little is known about its role in national health systems in the developing world (7).

According to the (8), majority of the population in low-income countries remains uncovered against the risk of illness. This is due to the fact that neither purely statutory social health insurance nor commercial insurance schemes alone can significantly contribute to increase coverage rates and thereby access to healthcare. In rural and remote areas, unit transaction cost of contracts is too high, leading often to a state of market failure (6). Therefore, in a bid to improve the health status of Nigerians, the government under the National Economic Empowerment Development Strategy (NEEDS), has decided to improve physical and financial access to good quality health services and also increase consumers awareness of their health rights and obligations. One of the ways with, which they hope to achieve this, was to develop and implement a comprehensive healthcare financing strategy, including the fast tracking of the National Health Insurance Scheme (NHIS) and to develop and implement a strategy to enhance community participation in providing and financing health services (9). The success of the scheme however, among other factors, will depend on rural household willingness to participate in the programme (10). It is important to note that the level of awareness of individual households about the scheme, will determine their acceptance of it. Also, the high level of poverty in Nigeria's rural areas is another factor to be considered. (11) also suggested that persons with health insurance may experience difficulties with financial access if their coverage does not extend to specific services or if deductibles are set at levels beyond their means to pay. Thus, large number of Nigerian citizens may not be able to afford payment for prepaid health insurance scheme as proposed by the government, even with its many benefits for both providers and buyers. Therefore, the shift towards health insurance is welcomed in principle, but means to achieving optimal public-private sector mix and participation of the intended beneficiaries remain a major challenge (12). Alternative forms of health care financing and cost-recovering strategies have been heavily criticized, the option of insurance seems to be a promising alternative as it is a possibility to pool risk transferring, unforeseeable healthcare costs, to fixed premiums (13). This study therefore examined the willingness-to-pay for Community Based Health Insurance by farming households in Kwara State, Nigeria.

\section{METHODOLOGY}

The study employed a combination of descriptive statistics and the contingency valuation methodology. The willingness to pay (WTP) for community based health insurance scheme in the study area was analysed using the contingent valuation method (CVM), Proposed by (14). The method has been used in many areas including environment, health, transport and marketing and has proven to be a useful instrument to obtain information on people's preferences for non-marketed goods. The CV method which belongs to the family of the so-called stated preference techniques is a "survey-based method frequently used for placing monetary values on environmental goods and services not bought and sold in the marketplace" (15). The contingent valuation survey includes; a detailed description of Hygeia community health plan, questions about willingness to pay for insurance scheme, questions about respondents' characteristics 
BABATUNDE R. O., et al.

(age, income, education, etc.) and the willingness-to-pay question which was defined in a way in which payment could be made (monthly, quarterly, annually, etc.). Thereafter, the average (mean) willingness to pay (WTP) per household head per month was estimated. The econometric model that was used to analyze the factors that determine the willingness to pay (WTP) by the respondents is implicitly stated as follows:

$Y f\left(X_{1}, X_{2}, X_{3}, X_{4}, X_{5} X_{6}, X_{7}, X_{8}, \ldots \ldots U\right) \ldots \ldots$ (1)

Where,

$\mathrm{Y}=$ Willingness to pay (Naira/Head/Year), and

$\mathrm{X}_{1}=$ Gender of Household Head( $\left.\mathrm{F}=0, \mathrm{M}=1\right)$

$\mathrm{X}_{2}=$ Educational levels of Household Head

(Years of schooling)

$\mathrm{X}_{3}=$ Age of Household Head (Years)

$\mathrm{X}_{4}=$ Primary occupation of Household Head

(Farming $=1,0$ otherwise)

$\mathrm{X}_{5}=$ Occupational experience (Years)

$\mathrm{X}_{6}=$ Household size

$\mathrm{X}_{7}=$ Total monthly expenditure of household (Naira)

$\mathrm{U}=$ Random error term

\section{DATA AND SAMPLE \\ CHARACTERISTICS}

The data used in this study were derived from a survey of farming household in Shonga, Bacita and Lafiagi districts of Edu Local Government Area of Kwara State, Nigeria. Kwara State was chosen for this study because of its high poverty incidence, its considerable socioeconomic heterogeneity and its location: it is among the six poorest states in Nigeria in terms of prevalence of undernourishment and income poverty. It has a good mixture of the three major ethnic groups in Nigeria and it is the gateway between the northern and southern regions. The State has a total population of about 2.4 million people, 70 per cent of which can be classified as smallholder farmers (16).

The sample consists of 175 farming households which were selected randomly using proportionality technique. Personal interviews were carried out with the household head, in the presence of other family members. A standardized questionnaire was used that covered information on the income, socioeconomic characteristics, and other contextual variables. Since the primary interest is to examine the willingness of the farming households to pay for community health insurance as well as its determinants, information on the types of insurance packages available to households, maximum amount household head was willing to pay for health insurance, total monthly expenditure of the household among others were also collected.

\section{RESULTS AND DISCUSSION Socio-economic characteristics of respondent}

Table 1 presents the definition and summary statistics of selected socioeconomic characteristics derived from the sampled households, which were later used as covariates in the econometric estimations.

Table 1. Summary statistics of variables used in the analysis.

\begin{tabular}{lcc}
\hline Variables & Mean & Standard Deviation \\
\hline Age (years) & 42.09 & 11.94 \\
Education (Years of Schooling) & 7.30 & 5.07 \\
Farm Size (Hectares) & 2.74 & 1.49 \\
Farming Experience (years) & 21.66 & 11.25 \\
Household Size (Adult Equivalent) & 4.56 & 1.80 \\
Total Asset (N '000) & 401 & 277.84 \\
Dependency ratio & 1.14 & 0.81 \\
Income (N '000) & 4.45 & 3.98 \\
Health Expense ((N '000)) & 0.68 & 0.48 \\
WTP( N/head/year) & 2139.43 & 3801.29 \\
\hline
\end{tabular}

Source: Data Analysis, 2014

Total Number of Observation $=175$

The variables as shown in Table 1 indicated that on the average, the age of the household head is 42 years, an indication that majority of the farming households are still in their prime age. Also, on the average, the household head has about 22 years of farming experience and has undergone about 7 years of schooling with a household size of about 5 persons. The mean household income and health expense are approximately $\$ 4,450.00$ and $\$ 680.00$ per month respectively. Also, most of the farming households in the area have just about 2.74 
BABATUNDE R. O., et al.

hectares of land for their farming activities. This shows that most of the farmers are subsistence farmers hence the small amount of income. Therefore an average farming household in this area will most likely require alternative mechanism of healthcare financing to be able to attend to their health issues.

\section{AWARENESS ABOUT HYGEIA COMMUNITY HEALTH PLAN}

Table 2 gives a summary of the level of awareness of the programme in the study area.

Table 2. Awareness about hygeia community health plan.

\begin{tabular}{lcc}
\hline Awareness & Frequency & Percentage \\
\hline Unaware & 3 & 1.7 \\
Aware & 172 & 98.3 \\
Total & 175 & 100.0 \\
\hline
\end{tabular}

Source: Field Survey, 2014

The result in Table 2 shows that only 1.7 per cent of the respondents are not aware of the Hygeia Community Health Plan while the remaining 98.3 per cent are aware of the health plan. This implies that majority of the respondents in the study area are aware of the proposed programme.

\section{MAXIMUM AMOUNT RESPONDENTS ARE WILLING-TO-PAY}

The maximum amount respondents are willing to pay for the health insurance scheme is given in Table 3.

Table 3. Maximum amount respondents are willing-to-pay.

\begin{tabular}{lcc}
\hline $\begin{array}{l}\text { WTP Amount } \\
\text { (Naira/Head/Annum) }\end{array}$ & Frequency & Percentage \\
\hline$<500$ & & \\
$500-1000$ & 25 & 14.3 \\
$1001-1500$ & 93 & 53.1 \\
$>1500$ & 9 & 5.1 \\
Total & 48 & 27.5 \\
Mean & 175 & 100.0 \\
Standard Deviation & 2139.43 & \\
\hline
\end{tabular}

Source: Field Survey, 2014

Table 3 shows that only 28 percent of the respondents are willing to pay more than N1500 per head per annum for health insurance in the area. The average amount households were willing to pay is N2, 139.43 per head per annum (1.1 USD per person per month). This implies that on the average households are willing to pay for health services since they are quite familiar with the plan as seen in Table 1. It may also be attributed to the fact that they are familiar with the satisfaction that can be derived from the Hygeia Community Health Plan. This finding is similar to those of $(17,18)$ for rural communities in eastern Nigeria where they obtained 1.5 USD (N2, 929.32) and 1.7 USD $(\mathrm{N} 3,319.90)$ per head per annum respectively. It is however different from that of (19) where the mean amount obtained was 3.26 USD (N522.00). This disparity can however be attributed to differences in the prevailing socioeconomic situations, and the cost of living as at the time the study was carried out.

\section{DETERMINANTS OF WILLINGNESS- TO-PAY FOR HYGEIA COMMUNITY HEALTH INSURANCE}

A summary of the determinants of willingness to pay for the Hygeeia community health insurance scheme is given in Table 4.

Table 4. Determinants of the maximum amount respondents are willing-to-Pay.

\begin{tabular}{lccc}
\hline Variables & Coefficient & Standard Error & t-value \\
\hline Age & $61.6163^{* *}$ & 29.792 & 2.07 \\
Gender & 2245.89 & 1969.80 & 1.14 \\
Years of Schooling & 26.7964 & 63.214 & 0.42 \\
Household size & -173.2095 & 223.279 & -0.78 \\
Farm size & $421.4926^{*}$ & 219.667 & 1.92 \\
Health expense & 0.0125 & 0.1500 & 0.08 \\
Monthly income & $0.8097^{* *}$ & 0.0374 & 2.16 \\
Constant & -2.332 .404 & 2490.05 & -0.94 \\
\hline
\end{tabular}

Source: Field Survey, 2014; *Significant at $10 \%$, ** Significant at 5\% 
BABATUNDE R. O., et al.

It can be deduced from table 4 that the age of household head was positively significant to the maximum amount he/she was willing to pay for the health insurance scheme at 5 per cent level of significance. This implies that older household heads are more willing to pay higher amount than the younger ones. In order words, a unit increase in the age of household head will result in a N61.62 increase in the amount he/she will be willing to pay all things being equal. This result is similar to that obtained by $(19,20)$. The size of the farmland cultivated by the household was found to be positively significant at 10 per cent level of significance. This may be because households with large farm size have the capacity to produce large quantity of output which turns out to large income thereby making the household head financially capable of paying higher amount for the health plan. The monthly income of household head was also significant at 5 per cent level of significance. This can be attributed to the fact that higher income will translate to increased ability to pay all things being equal. This is also consistent with the findings of $(19,10)$.

The gender of household head, years of schooling of household head and health expense were positively related but not significant while the household size was negatively related. The signs of these variables agree with a-priori expectation despite the fact that they are not significant. This may be because female headed household used in the study were relatively very few while the household size and monthly health expense only varied slightly. These variables might become significant by probably increasing the sample size.

\section{CONCLUSION AND RECOMMENDATIONS}

From the results of the study, it can be concluded that farming households are willing to pay for private health insurance scheme such as the Hygeia Community Health Plan. Also, the significant determinants of the amount these households are willing to pay include the age of the household head, farm size and monthly income of the household age. The study therefore recommended that government and private organization should work together to design and manage the implementation of health insurance schemes targeted at the rural farming households. Also, the government should provide an enabling environment for the establishment and operation of other insurance schemes that can help in the universal health coverage of the vulnerable groups in the nation. All these will help increase the quality of labour available for production purposes and in turn enhance sustainable development.

\section{REFERENCES}

1. World Health Organisation (WHO)., Social health protection. World Health Organization, Factsheet No.320, 2007.

2. Das, J., Hammer, J., and Leonard, K., The quality of medical advice in low-income countries, Journal of Economic Perspectives, 22(2), 93-114, 2008.

3. Van Damme, W., Van Leemput, L., Por, I., Hardeman, W., and Meessen, B., Out-ofpocket health expenditure and debt in poor households: Evidence from Cambodia, Tropical Medicine and International Health, 9(2), 273-280, 2004.

4. Annear, P., WHO Study of financial access to health services for the poor in Cambodia. World Health Organisation Research report, 2006. Retrieved from http://www.who.int/health_financing/docu ments/cov-cam-healthaccess-study/en/

5. World Health Organisation (WHO)., Make every mother and child count. World Health Organization Report, 2005.Retrieved from http://www.who.int/whr/2005/whr2005_en. pdf

6. Jutting, J. P., Do community-based health insurance schemes improve poor people's access to health care? Evidence from Rural Senegal, World Development 32(2):273288, 2004.

7. Sekhri, N., and Savedoff, W., Private health insurance: implications for developing countries, Bulletin of the World Health Organization 83:127-134, 2005.

8. World Bank, World development report, Nigeria, 1994. Retrieved from http://www.worldbank.org/external/countrie s/africaext/nigeriaextn/.

9. Nigerian Population Commission, Nigerian Demographic and Health Survey Abuja, Nigeria, 2004.

10.Oriakhi H. and Onemolease E., Determinants of rural household's willingness to participate in communitybased health insurance in Edo State, Nigeria, Ethno Med 6(2): 95-102, 2010.

11.Musau S.N., Community-based health insurance: Experiences and lessons learned from East Africa. Technical Report No. 34. Bethesda, MD: Partnerships for Health Reform Project, Abt Associates Inc, 1999.

12. Oyekale S. and Eluwa C., Utilization of healthcare and health insurance among rural Households in Irewole Local Government, Osun State, Nigeria. International Journal of Tropical Medicine 4(2): 70-75, 2009. 
13. Griffin, C. C., Health care in Asia: A comparative study of cost and financing. World Bank Regional and Sectoral Studies, Washington, D C, 1992.

14.Davis, R.K., The value of Outdoor Recreation: An Economic Study ofthe Maine Woods. Dissertation, Harvard University, 1963.

15.Carson, R., "Contingent Valuation - A user's guide". Environmental Science and Technology 34(8): 1413-1418, 2000.

16. National Bureau of Statistics Report 2006

17.Ichoku E.H, Fonta W and Atagbua J., Estimating the willingness to pay for community health insurance schemes in Nigeria: A random valuation framework, The IUP Journal of Risk and Insurance 7(1):7-27, 2010.
BABATUNDE R. O., et al.

18. Onwujekwe O., Onoka C., Uzochukwu B., Okoli C., Obikeze E., and Eze S., Is community-based health insurance an equitable strategy for paying for health care? Experiences from Southeast Nigeria, Health Policy 92(1):96-102, 2010.

19.Babatunde O., Akande T., Salaudeen A., Aderibigbe S., Elegbede O. and Ayodele L., Willingness to pay for Community Health Insurance and Its determinants among Household heads in Rural communities in North central, Nigeria. International Review of Social Sciences and Humanities 2(2): 133-142, 2011.

20.Donfouet, H. P. P. and Makaudze, E. M., Economic Value of the Willingness-to-pay for community Based Prepayment Scheme in Rural Cameroun. International Labour Organisation Research Paper No 3, 2011. 